\title{
PENINGKATAN PENGETAHUAN REMAJA TENTANG PENTINGNYA MINUM TABLET Fe SAAT MENSTRUASI DI SMA BK 06 JUWANGI
}

\author{
Suparmi $^{1}$, Istiqomah Risa Wahyuningsih ${ }^{2}$ \\ ${ }^{1}$ Prodi DIII Kebidanan STIKES Aisyiyah Surakarta \\ ${ }^{2}$ Prodi DIII Kebidanan STIKES Aisyiyah Surakarta \\ E-mail:mamikkajad@yahoo.co.id
}

\begin{abstract}
Menarche and menstruation begin to occur accompanied by the disposal of a number of Fe Menarche is the first menstruation of women that generally occurs around the age of 10-11 years. The output produced is an increase in adolescent knowledge about anemia and the benefits of Fe. The method of service used in the partner group was counseling to young women at BK 06 Vocational High School class X. Who had previously conducted a pre-test and post-test to determine adolescent knowledge about anemia and the benefits of Fe. At the beginning of the activity the extension team introduced activities followed by giving a questionnaire to determine the level of knowledge of young female students about anemia and the benefits of Fe. Of the 35 adolescents all have experienced menstruation. The results of the pre-test and post-test analysis were carried out, it was seen that the level of knowledge of the counseling participants before and after the provision of information experienced an increase in knowledge. Before giving counseling to teenagers who knew about the benefits of Fe there were 10 female students, after being given counseling there were 30 female students. Providing information to adolescents in the form of counseling on Mentrasi, Anemia, and the Importance of Fe is very necessary for adolescents who experience anemia, because one of the effects of anemia is affecting student achievement.
\end{abstract}

Keywords: Knowledge; Anemia; Fe Tablets

\section{PENDAHULUAN}

Remaja perempuan mulai terjadi menarche dan mensis disertai pembuangan sejumlah Fe (Manuaba, 2011). Menarche merupakan menstruasi pertama perempuan yang umumnya terjadi pada usia sekitar 1011 tahun. Menstruasi merupakan siklus yang kompleks karena melibatkan berbagai unsur dalam tubuh perempuan, diantaranya panca indra, korteks serebri, hipotalamus, aksis hipofisis-ovarium dan organ tujuan (uterus, endometrium serta organ seks sekunder). Menstruasi sesungguhnya yang disertai ovulasi sebagian besar dicapai pada umur sekitar 17-18 tahun (Manuaba, 2011). 


\section{GEMASSIKA: Jurnal Pengabdian Kepada Masyarakat}

Vol. 4 No. 1 Mei 2020

Remaja putri adalah salah satu kelompok yang rawan terhadap defisiensi zat besi, dapat mengenai semua kelompok status sosial-ekonomi, terutama yang berstatus sosial-ekonomi rendah (Soetjiningsih, 2010). Pada saat remaja putri sedang dalam masa pertumbuhan puncak (peak growth) dibutuhkan zat besi yang lebih tinggi yaitu untuk kebutuhan basal tubuh dan pertumbuhan itu sendiri. Satu tahun setelah peak growth, remaja putri biasanya akan mengalami haid pertama (menarche). Kebutuhan zat besi yang tinggi pada saat peak growthakan menetap karena selanjutnya diperlukan untuk menggantikan zat besi yang hilang pada saat menstruasi atau haid yaitu perdarahan secara periodik dan siklik dari uterus, disertai pelepasan endometrium (Wijanarko, 2007).

Remaja putri yang sedang menstruasi volume darah yang hilang selama menstruasi berkisar antara 25-30 cc perbulan (Dito, 2007). Anemia disebabkan karena peningkatan kebutuhan tubuh terutama pada remaja.Salah satu faktor penyebab anemia pada wanita adalah terjadinya kehilangan darah pada saat menstruasi, banyaknya darah yang keluar berperan pada kejadian dalam tubuh tidak dapat menggantikan hilangnya zat besi saat menstruasi.Kebanyakan pada remaja putri saat menstruasi tidak mengkonsumsi tablet Fe dikarenakan pada saat mengkonsumsi tablet Fe terasa mual dan kurangnya pengetahuan tentang pentingnya mengkonsumsi tablet $\mathrm{Fe}$. Anemia yang diderita oleh remaja putri dapat menyebabkan menurunnya prestasi belajar, menurunnya daya tahan tubuh sehingga mudah terkena penyakit infeksi (Wijiastuti, 2009).

Zat besi adalah salah satu unsur penting dalam proses pembentukan sel darah merah. Zat besi secara alamiah diperoleh darimakanan.Kekurangan zat besi secara berkelanjutan dapat menimbulkan penyakit anemia gizi atau yang dikenal masyarakat sebagai penyakit kurang darah (Path, 2004). Suplementasi pemberian tablet tambah darah dalam program penanggulangan anemia gizi telah dikaji dan diuji secara ilmiah efektivitasnya apabila dilaksanakan sesuai dosis dan ketentuan. Dianjurkan agar WUS mulai mengkonsumsi tablet tambah darah ketika memasuki usia remaja, saat menjelang pranikah (calon pengantin), masa kehamilan dan nifas serta selama masih mendapatkan haid (Depkes R.I, 2008).

Pengaruh kekurangan zat besi terutama melalui kondisi gangguan fungsi hemoglobin (Hb) yang merupakan alat transportasi O2 yang diperlukan pada banyak reaksi metabolik tubuh. Pada anak-anak sekolah 
telah ditunjukkan adanya hubungan erat antara kadar $\mathrm{Hb}$ dan kesanggupan anak untuk belajar.

Dikatakan bahwa pada kondisi anemia daya konsentrasi dalam belajar tampak menurun (Depkes R.I, 2008).

Data Survei Kesehatan Rumah Tangga (SKRT) tahun 2007 menyatakan bahwa prevalensi anemia gizi pada balita 40,5\%, ibuhamil 50,5\%, ibu nifas $45,1 \%$, remaja putri usia (10-18 tahun) 57,1\% dan usia 1945 tahun 39,5\%. Dari semua kelompok umur tersebut wanita mempunyai resiko paling tinggi untuk menderita anemia, terutama remaja putri (SKRT, 2007). Dari hasil wawancara dengan siswi SMA BK Juwangi dari 5 siswa ada 3 siswa yang tidak tahu tentang pentingnya minum Fe saat mentruasi. Tujuan dari penyuluhan tentang pentingnya Tablet Fe untuk mengatasi anemia pada remaja adalah untuk memberikan informasi kepada siswa yang belum mengetahui tentang anemia dan cara mengatasi anemia.

\section{MASALAH, TARGET DAN LUARAN}

Permasalahan kelompok mitra berdasarkan wawancara dari 5 siswa ada 3 siswa yang belum tahu tentang manfaat fe saat mentruasi.

Dari data tersebut menunjukkan tingkat pengetahuan remaja putri tentang pentingnya minum tablet Fe saat mentruasi di SMK BK Boyolali sangat kurang.

Tolak ukur sebelum pemberian penyuluhan tentang pentingnya minum tablet Fe saat mentruasi adalah pengetahuan remaja putri yang kurang. Luaran yang dihasilkan dari penyuluhan ini adalah adalah

1. Peningkatan pengetahuan remaja putri tentang pentingnya minum tablet Fe saat mentruasi.

2. Poster sebagai media promosi untuk mencegah anemia pada remaja putri dengan minum tablet $\mathrm{Fe}$ saat mentruasi.

3. Jurnal ilmiah sebagai tambahan referensi untuk program selanjutnya.

\section{METODE PELAKSANAAN}

Metode dalam pengabdian yang digunakan pada kelompok mitra yaitu dengan penyuluhan kepada remaja putri di SMK BK 06 Juwangi kelas X yang berjumlah 35 siswi,

Tehnik pengumpulan data dengan menyebarkan kuesioner tingkat pengetahuan tentang mentruasi, tablet $\mathrm{Fe}$ dan anemia. Pengumpulan data dilakukan sebelum penyuluhan dilakukan pre-test dan sesudah penyuluhan dilakukan penilaian lagi untuk mengetahui pengetahuan remaja tentang pentingnya minum tablet Fe saat mentruasi. 


\section{HASIL DAN PEMBAHASAN}

Pengabdian masyarakat yang dilakukan di SMA BK 06 Juwangi di laksanakan dengan melibatkan 35 siswi kelas X. pada awal kegiatan dilakukan kegiatan perkenalan tim penyuluh dilanjutkan dengan pemberian kuesioner untuk mengetahui tingkat pengetahuan siswa remaja putri tentang anemia dan manfaat Fe. Dari 35 Remaja semuanya sudah mengalami mentruasi.

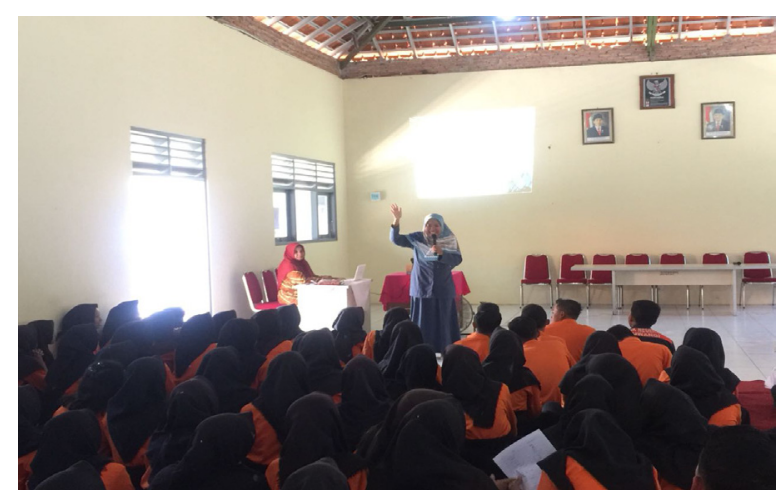

Gambar 1.

Pelaksanaan Penyuluhan di SMK BK 06 Juwangi.

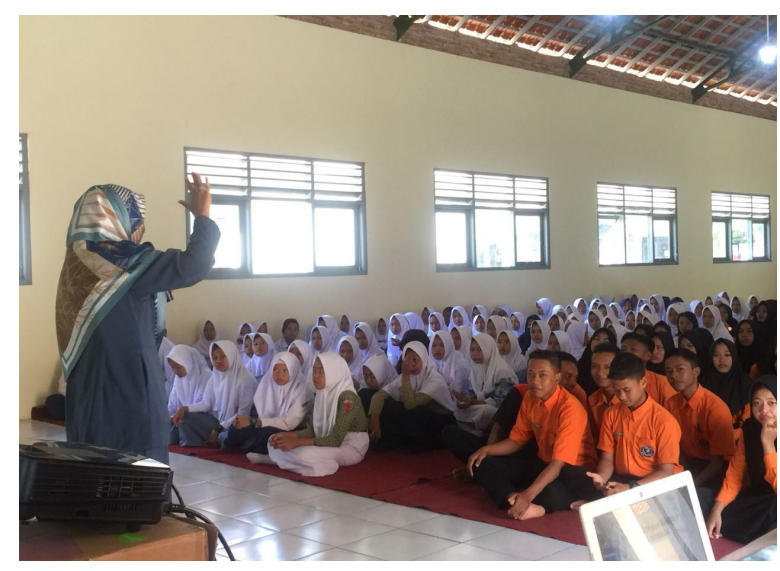

Gambar 2.

Pelaksanaan Penyuluhan di SMK BK 06 Juwangi.

\section{Grafik 1.}

Jumlah Remaja yang mengalami mentruasi di SMK BK 06 Juwangi.

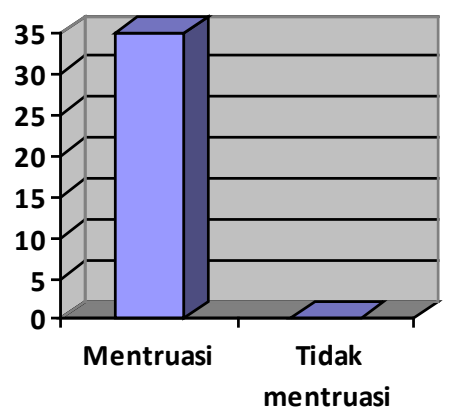

Remaja

Berdasarkan grafik 1 menunjukkan Jumlah remaja putri di SMA BK Boyolali yang mengalami mentruasi sebanyak 35 siswa.

\section{Grafik 2}

Pengetahuan remaja putri tentang Anemia sebelum diberikan Penyuluhan (pre-test)

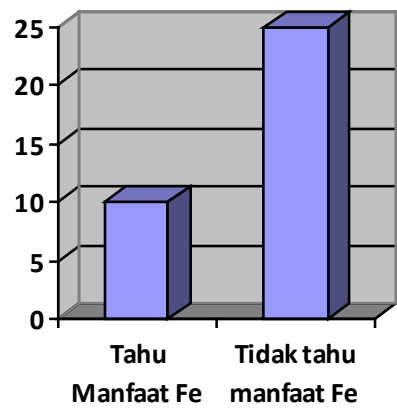

$\square$ Pengetahuan

Remaja

Berdasarkan grafik 2 menunjukkan Tingkat pengetahuan remaja putri di SMA BK sebelum diberikan penyuluhan tentang pentingnya tablet $\mathrm{Fe}$ saat mentruasi ada 10 siswa yang sudah tahu pp sedangkan siswa yang belum atahu tentang pentingnya tablet Fe saat mentruasi ada 25 siswa. 
Grafik 3.

Pengetahuan remaja putri tentang manfaat fe setelah diberikan Penyuluhan (post-test)

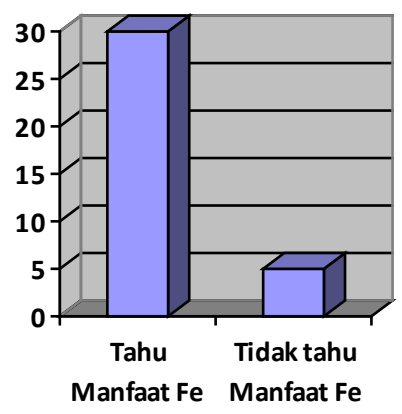

$\square$ Pengetahuan Remaja

Berdasarkan grafik 3 menunjukkan tingkat pengetahuan remaja putri di SMA BK sesudah diberikan penyuluhan tentang pentingnya tablet $\mathrm{Fe}$ saat mentruasi ada 30 siswa yang tingkat pengetahuannya meningkat. Dan masih ada 5 siswa yang pengetahuannya masih sama.

Hasil analisis pre test dan post test yang dilakukan, terlihat bahwa tingkat pengetahuan peserta penyuluhan sebelum dan sesudah pemberian informasi mengalami peningkatan pengetahuan. Sebelum diberikan penyuluhan remaja yang tahu tentang manfaat Fe ada 10 siswi, setelah diberikan penyuluhan ada 30 siswi.

Pendidikan kesehatan diberikan sebagai upaya memberikan penjelasan kepada perorangan. Kelompok untuk menumbuhkan pengertian, dan kesadaran mengenai perilaku sehat saat menghadapi mentruasi dan bila terjadi disminore. Pendidikan kesehatan yang digunakan adalah sosialisasi.

Tujuan utama pendidikan kesehatan adalah agar orang mampu menerapkan masalah dan kebutuhan mereka sendiri, mampu memahami apa yg dapat mereka lakukan terhadap masalahnya, dengan sumber daya yg ada pada mereka ditambah dengan dukungan dari luar, dan mampu memutuskan kegiatan yg tepat guna untuk meningkatkan tarafhidup sehat dan kesejahteraan masyarakat (Mubarak, 2009).

Menurut Mubarak (2009) dalam Undangundang Kesehatan No. 23 Tahun 1992 dan WHO menyebutkan tujuan pendidikan kesehatan adalah meningkatkan kemampuan masyarakat untuk memelihara dan meningkatkan derajat kesehatan; baik secara fisik, mental dan sosialnya, sehingga produktif secara ekonomi maupun social, pendidikan kesehatan disemua program kesehatan; baik pemberantasan penyakit menular, sanitasi lingkungan, gizi masyarakat, pelayanan kesehatan, maupun program kesehatan lainnya (Mubarak, 2009).

Zat besi (Fe) secara alamiah diperoleh dari makanan. Sumber utama zat besi adalah bahan pangan hewani dan kacang-kacangan serta sayuran berwarna hijau tua. Kesulitan utama untuk memenuhi kebutuhan Fe adalah 


\section{GEMASSIKA: Jurnal Pengabdian Kepada Masyarakat}

Vol. 4 No. 1 Mei 2020

rendahnya tingkat penyerapan zat besi dalam tubuh, terutama zat besi nabati hanya diserap 1-2 \%, sedangkan tingkat penyerapan zat besi makanan asal hewani dapat mencapai 10-20\%. Ini berarti zat besi Fe pangan asal hewani lebih mudah diserap daripada zat besi pangan asal nabati. Keanekaragaman konsumsi makanan berperan penting dalam membantu meningkatkan penyerapan $\mathrm{Fe}$ didalam tubuh. Kehadiran protein hewani seperti daging, ikan dan telur, vitamin C, vitamin A, zink ( $\mathrm{Zn})$, asam.folat, zat gizi mikrolain dapat meningkatkan penyerapan zat besi dalam tubuh (Depkes R.I, 2005)

Penyuluhandidalampengabdiankesehatan masyarakat ini bertujuan untuk meningkatkan pengetahuan tentang pentingnya Minum Fe saat menstruasi pada Remaja di SMA BK 06 Juwangi Kabupaten Boyolali. Penyuluhan yang diberikan meliputi pemberian informasi tentang menstruasi, Anemia, Fe dan cara mengatasi Anemia. Jadi tujuan pendidikan kesehatan adalah peningkatan pengetahuan dan pemahaman pentingnya kesehatan untuk tercapainya perilaku kesehatan sehingga dapat meningkatkan derajat kesehatan fisik, mental dan sosial, sehingga produktif secara ekonomi maupun sosial.

Pengaruh kekurangan zat besi terutama melalui kondisi gangguan fungsi hemoglobin
(Hb) yang merupakan alat transportasi O2 yang diperlukan pada banyak reaksi metabolik tubuh. Pada anak-anak sekolah telah ditunjukkan adanya hubungan erat antara kadar $\mathrm{Hb}$ dan kesanggupan anak untuk belajar. Dikatakan bahwa pada kondisi anemia daya konsentrasi dalam belajar tampak menurun (Manuaba, 2011).

\section{KESIMPULAN DAN SARAN}

Pemberian informasi kepada remaja berupa penyuluhan tentang Mentruasi, Anemia, dan Pentingnya $\mathrm{Fe}$ sangat diperlukan untuk remaja yang mengalami Anemia, karena salah satu dampak anemia adalah mempengaruhi prestasi siswa. Sehingga para remaja putri jadi meningkat pengetahuannya tentang pentingnya minum tablet Fe saat mentruasi yang bermanfaat untuk mencegah anemia. Diharapkan hasil sosialisasi ini bermanfaat untuk masyarakat. Sehingga masalah yang dialami remaja yang berhubungan dengan Anemia pada remaja di SMA BK 06 Juwangi dapat diatasi. Untuk selanjutnya perlu dilakukan sosialisasi ditempat lain, karena masih banyak remaja putri dan masyarakat belum mengetahui pentingnya minum tablet $\mathrm{Fe}$ saat mentruasi untuk mencegah Anemia pada Remaja. 


\section{DAFTAR PUSTAKA}

Departemen Kesehatan. (2005). Pengetahuan, Sikap, dan Perilaku Remaja tentang Kesehatan Reproduksi. Diakses melalui

Departemen Kesehatan. (2008). Kesehatan Remaja: Problem dan Solusinya. Jakarta. Salemba Medika

DepKes RI. (2007). Survei Kesehatan Rumah Tangga (SKRT). Salemba Medika: Jakarta.

Manuaba. (2011). Memahami Kesehatan Reproduksi Wanita. Jakarta: EGC.

Mubarak. 2009. Promosi Kesehatan Sebuah Pengamatan Proses Belajar Mengajar dalam Pendidikan. Jokjakarta: Graha Ilmu.

Notoatmojo. (2010). Tumbuh Kembang Remaja dan Permasalahannya. Jakarta: PT Rireka Cipta . (2010). Pendidikan dan Perilaku Kesehatan. Jakarta: PT. Rineka.

Cipta Proverawati, A dan Misaroh, S. (2009). Menarche Menstruasi Penuh Makna Yogyakarta: Nuha Medika.

Paath, E. F., 2005. Gizi dalam Kesehatan Reproduksi. Penerbit Buku Kedokteran. Jakarta: EGC.

Soerjono. 2005. Pembelajaran Quantum Learning. Bandung: Aglesindo.

Soetjiningsih. 2010.Tumbuh Kembang Remaja dan Permasalahannya. Jakarta: Sagung Seto.

Widyastuti. 2009. Kesehatan Reproduksi. Yogyakarta: Fitramaya; 2009. 